\title{
The metals disconnect
}

\author{
Economic development in a sustainable fashion is metals-intensive. If we cannot afford to ban mining, \\ regulation must be more effective.
}

The sustainable development goals - the United Nation's 17 goals to transform the world by 2030 - aim to bring about many benefits to human society, including safe and resilient cities, economic growth, clean energy and an end to poverty (http:// go.nature.com/2cJRMdi). Achieving these goals requires access to a larger quantity and broader range of natural resources than are easily accessible ${ }^{1}$. Low-carbon, renewable energy sources, for example, which include wind turbines and solar panels, are highly metals-intensive ${ }^{2}$. Yet, public opposition to mining is stronger than ever, making it increasingly difficult to open new mines.

This disconnect was the focus of numerous discussions at the 35 th International Geological Congress - a meeting of geoscientists and industry specialists held recently in Cape Town, South Africa (http://www.35igc.org/). Both the public's perception of and industry's approach to mining must change. As a society we need to accept that sustainable, economic development will not be possible without a new supply of metals ${ }^{1}$. At the same time, governments as well as the mining industry must ensure exploitation does not ruin the planet, by pursuing more tightly regulated, greener delivery of these resources.

\section{Sustainable, economic}

\section{development means new mines somewhere on the globe.}

The Earth's population is predicted to expand to over nine billion by 2050. Much of the increase will be absorbed by urban migration, as those living in rural poverty move to cities to find work. To provide cities with infrastructure that is resilient to natural disasters, to aid economic growth in under-developed nations, and to build low-carbon energy sources, we need a large supply of natural resources. Add to that the rising demands from individuals for more and better gadgets, cars and homes, all of which are composed of an array of metals. These materials come largely from mining. Yet, mining proposals face strong opposition from the general public. Clearly, the public fail to connect mining to mineral

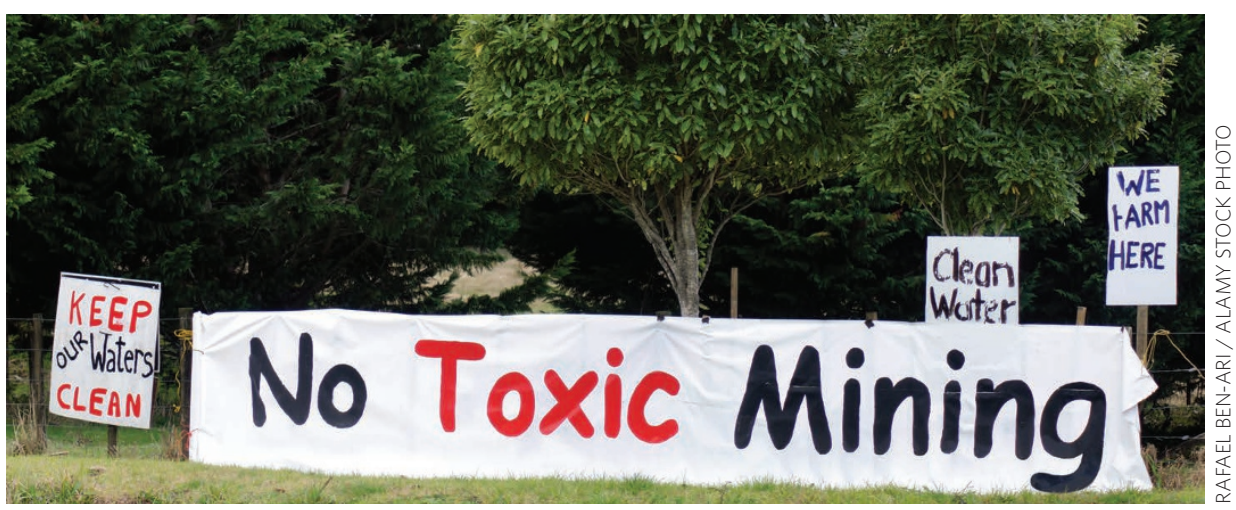

consumption at both a global and an individual level ${ }^{1}$.

Mining's bad reputation is not unwarranted. In just two recent examples, an explosion at a mine in Soma, Turkey in 2014 created a fire that burned for two days, killing at least 301 people. And a wastewater spill at the Gold King Mine in Colorado, USA, in 2015 released three million US gallons of toxic waste into the Animas River, damaging crops and cattle herds. Mining activities can have a devastating impact on local communities and the environment. It is unsurprising then that people resist plans to open or expand mines close to home. And community mobilization can be powerful - protests are often successful in preventing or substantially delaying mining projects. Such opposition is no longer restricted to those fighting to protect their own patch ${ }^{3}$. NIMBYism (not in my back yard) has shifted to BANANAism (build absolutely nothing anywhere near anything) - without giving any thought to the question of how we can possibly achieve sustainable, economic development if mining proposals are rarely approved anywhere.

Societies must negotiate their paths between the goals of economic development, sustainability and avoiding environmental impacts from mining. Sustainable, economic development means new mines somewhere on the globe. Fierce opposition to a mine opening in one region can lead to an expansion of mining elsewhere - typically in lessdeveloped nations where safety standards, environmental protection and law enforcement might be more relaxed - and can amount to outsourcing of pollution and risk. To navigate geopolitical constraints and ensure ethical sourcing of minerals and metals ${ }^{4}$, developed nations in particular must be prepared to accept mining on home soil or significantly reduce their usage of metals and minerals.

At the same time, the onus is on the mining industry to guarantee the use of more-regulated, greener mining practices and to ensure that the host nation benefits from their operations. Governments and policymakers must also set in place tighter environmental restrictions and ensure that mining companies are held responsible for any breaches or accidents. More research is needed, too, on how we can meet the demands of a sustainable future with improved mining methods, recycling and product design, as well as by designing alternative materials from more readily available elements.

It is time to fully acknowledge that geoscience is not only about the planet, but also about the people that populate it. If we can integrate the geologic, economic and social sciences ${ }^{3,5}$, we can go a long way toward bridging the disconnect between demand and supply.

\footnotetext{
References

1. Nickless, E. Delivering sustainable development goals: the need for a new social contract for mining. In 35th International Geological Congress (2016).

2. Vidal, O., Goffé, B. \& Arndt, N. Nat. Geosci. 6, 894-896 (2013).

3. Jébrak, M., Bergeron, K. M., Gunzburger, Y., Kister, P. \& Piguet, J. P. Mining industry and society: our new and challenging frontier. In 35th International Geological Congress (2016); http:// go.nature.com/2coNDuX

4. Herrington, R. Nat. Geosci. 6, 892-894 (2013).

5. Mata-Perello, J. M. DYNA-Colombia 79, 158-166 (2012).
} 